\title{
Transformation of Ginsenosides Rb2 and Re from Panax ginseng by Food Microorganisms
}

\author{
Hyun CHI, ${ }^{a}$ Dong-Hyun KIm, ${ }^{b}$ and Geun-Eog $\mathrm{J}_{\mathrm{I}}{ }^{*, a, c}$ \\ ${ }^{a}$ Department of Food and Nutrition, Seoul National University; 56-1 Shinlim-dong, Kwanak-ku, Seoul 151-742, South \\ Korea: ${ }^{b}$ College of Pharmacy, Kyung Hee University; 1 Hoegidong, Dongdaemu-ku, Seoul 130-701, South Korea: and \\ ${ }^{c}$ Research Center, BIFIDO Co., Ltd.; Seoul 151-818, South Korea. Received April 4, 2005; accepted June 2, 2005
}

Protopanaxadiol ginsenosides $\mathrm{Rb2}$ and $\mathrm{Rc}$ were transformed using cell-free extracts from various edible food microorganisms and then analyzed by TLC and HPLC. Rb2 and Re were transformed into compound $\mathrm{K}$ via Rd and F2 by Bifidobacterium sp. Int57 and Bifidobacterium sp. SJ32. Lactobacillus delbrueckii transformed Rb2 and Rc into ginsenoside Rh2. Bifidobacterium sp. SH5 transformed Rb2 and Rc into F2. Aspergillus niger transformed $\mathrm{Rb} 2$ into compound $\mathrm{K}$ via compound $\mathrm{O}$ and compound $\mathrm{Y}$, whereas it transformed $\mathrm{Rc}$ into compound $\mathrm{K}$ via Mc. Taken together, these processes would allow a specific bioconversion process to obtain specific ginsenosides using an appropriate combination of ginsenoside substrates and specific microbial enzymes.

Key words ginsenoside; transformation; food microorganism; microbial cell extract

Ginseng (the root of Panax ginseng C. A. Meyer; family Araliaceae) is used worldwide for the prevention of various diseases. Ginseng saponins (ginsenosides) are the principal components having pharmacological and biological activities, such as antidiabetic, and anti-tumor activities. ${ }^{1,2)}$ More than 30 different ginsenosides so far have been isolated and identified from ginseng saponins. Among them, the abbreviations of the ginsenosides analyzed in this study are shown in Table 1. The main ginsenosides are glycosides that contain an aglycone with a dammarane skeleton, and include protopanaxadiol-type saponins such as ginsenosides $\mathrm{Rb} 1, \mathrm{Rb} 2$, $\mathrm{Rc}$ and $\mathrm{Rd}$, and protopanaxatriol-type saponins such as ginsenosides $\operatorname{Re}$ and $\operatorname{Rg} 1$. Among them, deglycosylated ginsenosides are known to be more readily absorbed into the bloodstream and to act as active compounds. ${ }^{3)}$ Intestinal microflora can transform ginsenosides into more active forms after ingestion of the ginsenosides. ${ }^{4)}$ Protopanaxadiol ginsenosides such as $\mathrm{Rb} 1, \mathrm{Rb} 2$, and $\mathrm{Rc}$ have previously been shown to be metabolized by human intestinal bacteria to their final derivative, compound $\mathrm{K}$, with the degree of the transformation of the ginsenosides and production of compound $\mathrm{K}$ differing between Eubacterium sp., Streptococcus sp., and Fusobacterium K-60.5) The efficiency of conversion and the transformation pathways may differ greatly due to the diversity of the resident microflora between individuals.5) The above observations have lead to many attempts to produce transformed ginsenosides. Some researchers have attempted to prepare genuine prosapogenins or sapogenin by chemical synthesis, mild acid hydrolysis, and alkaline cleavage. ${ }^{6,7)}$ However, these methods are associated with inevitable and undesirable side reactions, such as epimerization, hydration, and hydroxylation. These problems have lead to microbial conversion $^{3,8-10)}$ and enzymatic conversion ${ }^{11,12)}$ to transform ginsenosides. Although several ginsenosides transformed by microorganisms were identified, investigations of the transformation pathway have been limited to only a few microorganisms. In addition, most of the microorganisms used for the transformation of ginsenosides in the previous studies were inedible. To rectify this, we instead used various microorganisms that have been safely used for foods consumption.

In this study we focused on the production of specific deglycosylated ginsenosides by using major protopanaxadiol ginsenosides $\mathrm{Rb} 2$ and $\mathrm{Rc}$ as substrates, along with enzyme preparations obtained from edible food microorganisms.

\section{MATERIALS AND METHODS}

Materials Standard Rc was purchased from Sigma Chemical (St. Louis, MO, U.S.A.). Rb2, F2, and Rh2 were purchased from LKT Laboratories (St. Paul, MN, U.S.A.). Rd was purchased from BTGin (Chungnam, Korea), and compound K was donated from the Department of Pharmaceutical Science, Kyung Hee University (Seoul, Korea).

Microbial Strains and Growth Conditions Bifidobacterium sp. Int57, Bifidobacterium bifidum BGN4, Bifidobac-

Table 1. Abbreviations for Ginsenosides

\begin{tabular}{|c|c|}
\hline Abbreviation & Full name \\
\hline $\mathrm{Rb} 2$ & 3- $O$-[ $\beta$-D-Glucopyranosyl-(1-2)- $\beta$-D-glucopyranosyl]-20- $O$-[ $\alpha$-L-arabinopyranosyl-(1-6)- $\beta$-D-glucopyranosyl]-20(S)-protopanaxadiol \\
\hline Rc & 3- $O$-[ $\beta$-D-Glucopyranosyl-(1-2)- $\beta$-D-glucopyranosyl]-20- $O$-[ $\alpha$-L-arabinofuranosyl-(1-6)- $\beta$-D-glucopyranosyl]-20(S)-protopanaxadiol \\
\hline $\mathrm{Rd}$ & 3- $O$-[ $\beta$-D-Glucopyranosyl-(1-2)- $\beta$-D-glucopyranosyl]-20- $O-\beta$-D-glucopyranosyl-20(S)-protopanaxadiol \\
\hline F2 & 3- $O-\beta$-D-Glucopyranosyl-20-O- $\beta$-D-glucopyranosyl-20(S)-protopanaxadiol \\
\hline Compound $\mathrm{K}$ & 20-O- $\beta$-D-Glucopyranosyl-20(S)-protopanaxadiol \\
\hline $\mathrm{Rh} 2$ & 3-O- $\beta$-D-Glucopyranosyl-20(S)-protopanaxadiol \\
\hline Compound $\mathrm{O}$ & 3- $O-\beta$-D-Glucopyranosyl-20-O-[ $\alpha$-L-arabinopyranosyl-(1-6)- $\beta$-D-glucopyranosyl]-20(S)-protopanaxadiol \\
\hline Compound $\mathrm{Y}$ & $20-O$-[ $\alpha$-L-Arabinopyranosyl-( $1-6)-\beta$-D-glucopyranosyl $]-20(S)$-protopanaxadiol \\
\hline Mc & 20-O-[ $\alpha$-L-Arabinofuranosyl-(1-6)- $\beta$-D-glucopyranosyl]-20(S)-protopanaxadiol \\
\hline
\end{tabular}


terium sp. SJ32, and Bifidobacterium sp. SH5 were isolated as reported previously. ${ }^{13)}$ Lactobacillus delbrueckii sp. delbrueckii KCTC 1047, Aspergillus niger KCTC 6906, and A. usamii var. shirousamii KCTC 6956 were purchased from the Korean Collection for Type Cultures (Daejeon, Korea). Bacterial strains were incubated in MRS broth (Difco) containing $0.05 \%(\mathrm{w} / \mathrm{v})$ L-cysteine $\cdot \mathrm{HCl}$ under anaerobic conditions overnight at $37^{\circ} \mathrm{C}$, and were subcultured in MRS broth and used for the incubation of ginseng extract or preparation of bacterial cell extract. A. niger KCTC 6906 was incubated in Potato Dextrose broth (Difco), and A. usamii var. shirousamii KCTC 6956 was incubated in Malt Extract broth (Difco) under aerobic conditions at $24^{\circ} \mathrm{C}$ for $7 \mathrm{~d}$ with shaking. Each mycelia or culture broth was used for incubation of ginseng extract or preparation of a crude enzyme.

Preparation of Crude Microbial Enzymes Bacteria (11 culture broth) were harvested by centrifugation $(3000 \times \boldsymbol{g}$ for $30 \mathrm{~min}$ at $4^{\circ} \mathrm{C}$ ), washed twice with $50 \mathrm{~mm}$ phosphate buffer (pH 6.0), resuspended in $50 \mathrm{ml} 50 \mathrm{~mm}$ phosphate buffer and disrupted in a high pressure cell disrupter (Stansted Fluid Power, Essex, U.K.). The culture broth $(500 \mathrm{ml})$ of $A$. niger KCTC 6906 was filtered, and then solid ammonium sulfate was added to the filtrate to give $80 \%$ saturation. The precipitate was collected by centrifugation $(15000 \times \boldsymbol{g}$ for $30 \mathrm{~min}$ at $4{ }^{\circ} \mathrm{C}$ ), dissolved in $5 \mathrm{ml} 50 \mathrm{~mm}$ phosphate buffer $(\mathrm{pH} 6.0)$, and dialyzed. The collected mycelia ( $500 \mathrm{ml}$ culture broth) of A. usamii var. shirousamii KCTC 6956 was resuspended in $200 \mathrm{ml} 50 \mathrm{~mm}$ phosphate buffer ( $\mathrm{pH}$ 6.0) and disrupted in a cell disrupter (Bead-Beater, Biospec Products, Bartlesville, OK, U.S.A.) by glass beads ( $0.5 \mathrm{~mm}$ in diameter $)$. The supernatant was then used as an enzyme solution after centrifugation $\left(5000 \times \boldsymbol{g}\right.$ for $30 \mathrm{~min}$ at $\left.4{ }^{\circ} \mathrm{C}\right)$.

Assay of $\boldsymbol{\beta}$-Glucosidase Activity To determine the glycosidase activity, $80 \mu \mathrm{l}$ of cell-free extracts of the cultured microorganisms were added to $20 \mu 15 \mathrm{~mm} p$-nitrophenyl- $\beta$ glucopyranoside, then the mixture was incubated at $37^{\circ} \mathrm{C}$ for $5 \mathrm{~min}$. The reaction was stopped by adding $100 \mu \mathrm{l}$ of $0.5 \mathrm{M}$ $\mathrm{Na}_{2} \mathrm{CO}_{3}$. The released $p$-nitrophenol (pNP) was measured at $450 \mathrm{~nm}$. One unit of enzyme activity was defined as the amount that released $1 \mu \mathrm{mol}$ pNP per minute, and specific activity was obtained per mg dry weight cell or $\mathrm{mg}$ protein.

Transformation of Ginsenosides by Crude Microbial Enzymes The reaction mixture $(100-2050 \mu \mathrm{l})$ containing $0.05 \mathrm{mg}$ of each ginsenoside in $50 \mu \mathrm{l} 20 \mathrm{~mm}$ acetate buffer (pH 5.0) and 50-2000 $\mu$ l of crude microbial enzyme was in- cubated at $37^{\circ} \mathrm{C}$ for various time periods. The reaction mixture was extracted with $200 \mu$ l of $n$-butanol, and the $n$-butanol fraction was analyzed by TLC and HPLC according to Bae et al. and Ko et al. ${ }^{12,14)}$

\section{RESULTS}

Transformation of Rb2 by Food Microbial Enzymes Various transformed products of $\mathrm{Rb} 2$ produced by cell-free extracts of the experimental food microorganisms were confirmed by TLC and HPLC analyses, and their ginsenoside levels are shown in Table 2. The experimental ginsenosides were not transformed by boiled enzyme preparations (data not shown). When ginsenoside $\mathrm{Rb} 2$ reacted with enzymes from various food microorganisms, the intermediate and final hydrolysis products of $\mathrm{Rb} 2$ were dependent on the microorganisms used. For instance, $2 \mathrm{mU}$ of Bifidobacterium sp. Int57 enzyme (Int57) transformed Rb2 into Rd or F2 by $24 \mathrm{~h}$. When the incubation time was increased up to $48 \mathrm{~h}$, Rd and F2 were transformed into compound K. From these results, the transformation pathways of Rb1 by Int57 was $\mathrm{Rb} 2 \rightarrow$ $\mathrm{Rd} \rightarrow \mathrm{F} 2 \rightarrow$ compound $\mathrm{K}$ as shown in Fig. 1. To reconfirm the above transformation process, we again tried having Rd or F2 react with Int57. The results matched the pathways shown in Fig. 1 (data not shown). The same strategy used for Int57 was applied to analyze the various transformation pathways of Rb2 by different experimental microorganisms (Fig. 1). Bifidobacterium sp. SJ32 enzyme (SJ32) also transformed $\mathrm{Rb} 2$ into compound $\mathrm{K}$ via $\mathrm{Rd}$ and $\mathrm{F} 2$, although Int57 was more active in the transformation of $\mathrm{Rb} 2$ into compound $\mathrm{K}$ than SJ32. L. delbrueckii enzyme (L. delbrueckii) transformed $\mathrm{Rb} 2$ into $\mathrm{Rh} 2$ via $\mathrm{Rd}$ and $\mathrm{F} 2$. Bifidobacterium sp. SH5 enzyme (SH5) transformed Rb2 into Rd, and then further transformed Rd into $\mathrm{F} 2$ without producing compound $\mathrm{K}$. $A$. niger enzyme ( $A$. niger) and $A$. usamii enzyme (A. usamii) transformed $\mathrm{Rb} 2$ into compound $\mathrm{K}$ via compound $\mathrm{O}$ and compound $\mathrm{Y}$.

Transformation of Re by Food Microorganisms Various transformed products and transformation pathways of Rc are shown in Table 3 and Fig. 2, respectively. Int57 and SJ32 transformed Rc into compound $\mathrm{K}$ via $\mathrm{Rd}$ and then $\mathrm{F} 2$, although Int57 was more active in the transformation of Rc into compound $\mathrm{K}$ than SJ32. SH5 also hydrolyzed the $\alpha$-arabinofuranose of Rc to produce $\mathrm{Rd}$, and then further transformed $\mathrm{Rd}$ into $\mathrm{F} 2$ without producing compound K. L. del-

Table 2. Concentrations of Ginsenosides Transformed from Rb2 ${ }^{a)}$ by Cell-Free Extracts ${ }^{b)}$ from Various Food Microorganisms

Transformed ginsenoside $(\mu \mathrm{M})$

\begin{tabular}{|c|c|c|c|c|c|c|c|c|c|c|c|c|c|c|}
\hline \multirow[t]{2}{*}{ Microbes } & \multicolumn{7}{|c|}{$24 \mathrm{~h}$} & \multicolumn{7}{|c|}{$48 \mathrm{~h}$} \\
\hline & $\mathrm{Rb} 2$ & $\mathrm{Rd}$ & $\mathrm{CO}^{c)}$ & $\mathrm{CY}^{d)}$ & $\mathrm{F} 2$ & $\mathrm{CK}^{e)}$ & Rh2 & $\mathrm{Rb} 2$ & $\mathrm{Rd}$ & $\mathrm{CO}$ & $\mathrm{CY}$ & $\mathrm{F} 2$ & CK & $\mathrm{Rh} 2$ \\
\hline Int57 & f) & 425 & - & - & 334 & 81 & - & - & - & - & - & 27 & 842 & - \\
\hline SJ32 & 314 & 89 & - & - & 427 & - & - & - & - & - & - & 79 & 794 & - \\
\hline SH5 & 75 & 788 & - & - & 17 & - & - & - & 84 & - & - & 803 & - & - \\
\hline L. del ${ }^{g)}$ & 336 & 18 & - & - & 223 & - & 381 & 98 & 27 & - & - & 102 & - & 605 \\
\hline A. niger & - & - & 515 & 343 & - & - & - & - & - & - & 784 & - & 88 & - \\
\hline A. usamii & - & - & 514 & 329 & - & - & - & - & - & - & 763 & - & 95 & - \\
\hline
\end{tabular}

a) $\mathrm{Rb} 2: 910 \mu \mathrm{M}$ in the original sample. b) Specific activities of $\beta$-glucosidase of the prepared microbial cell-free extracts and amounts of enzymes used for the transformation reactions were: Int $57,0.50 \mathrm{mU} / \mathrm{mg}$ dry wt. cell, $2 \mathrm{mU} ; \mathrm{SJ} 32,0.42 \mathrm{mU} / \mathrm{mg}$ dry wt. cell, $2 \mathrm{mU} ; \mathrm{SH} 5,0.28 \mathrm{mU} / \mathrm{mg}$ dry wt. cell, $20 \mathrm{mU} ; L$. delbrueckii, $0.15 \mathrm{mU} / \mathrm{mg} \mathrm{dry} \mathrm{wt.} \mathrm{cell,}$ $20 \mathrm{mU} ;$ A. niger, $0.25 \mathrm{mU} / \mathrm{mg}$ protein, $10 \mathrm{mU} ;$ A. usamii, $0.23 \mathrm{mU} / \mathrm{mg}$ protein, $10 \mathrm{mU}$, respectively. c) CO: compound O. $\quad d$ ) CY: compound Y. e) CK: compound $\mathrm{K}$. $f$ ) Below $10 \mu \mathrm{M}$. g) L. del: L. delbrueckii. 
brueckii hydrolyzed the $\alpha$-arabinofuranose of Rc to produce $\mathrm{Rd}$, which was further transformed into Rh2 via F2. A. niger transformed Rc into compound $\mathrm{K}$ via compound Mc. A. usamii ultimately transformed Rc into compound $\mathrm{K}$, but the pathway was not determined in the present study.

\section{DISCUSSION}

Intestinal microflora can transform ginsenosides into more active forms after ingestion of ginsenosides. ${ }^{4)}$ Protopanaxadiol ginsenosides such as $\mathrm{Rb} 1, \mathrm{Rb} 2$, and Rc have previously been shown to be metabolized by human intestinal bacteria to their final derivative, compound $\mathrm{K}$, with the degree of

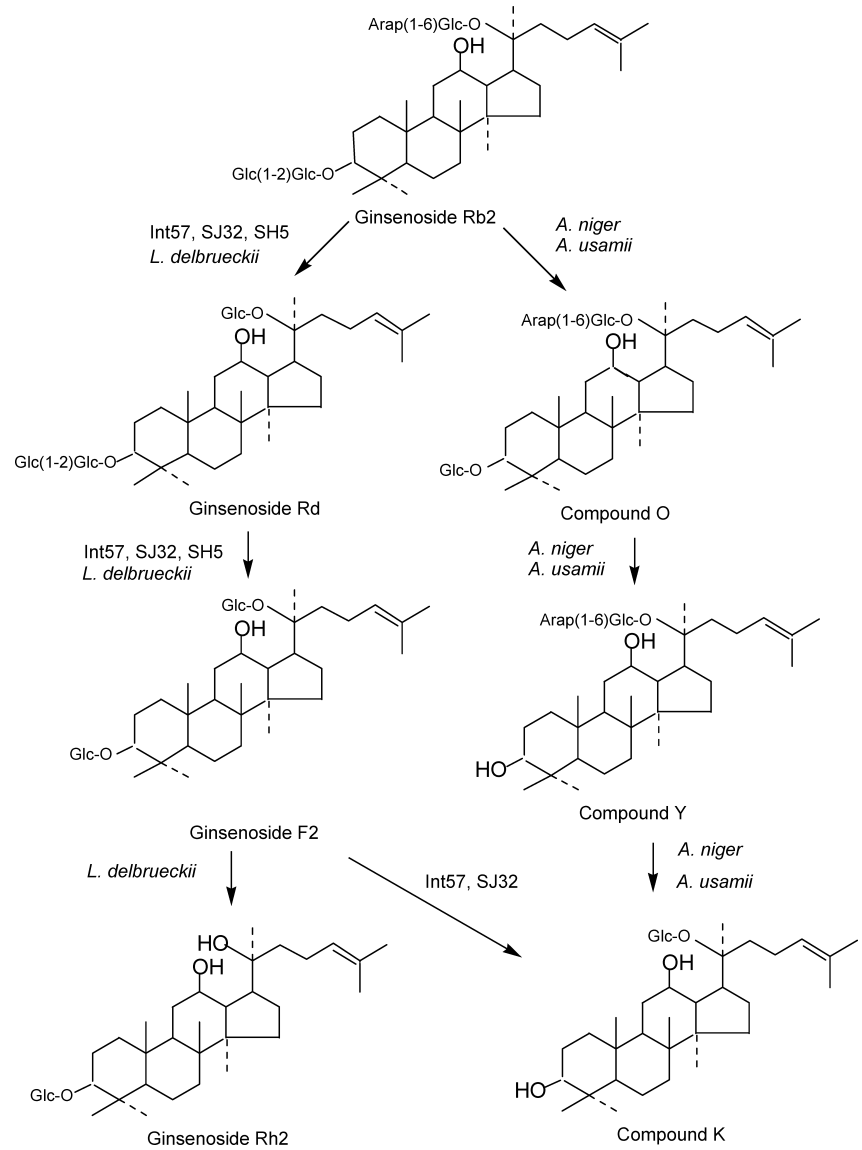

Fig. 1. Proposed Transformation Pathways of Rb2 by Cell-Extracts from Various Food Microorganisms transformation of the ginsenosides and production of compound K differing between Eubacterium sp., Streptococcus sp., and Fusobacterium K-60., ${ }^{3,4)}$ The efficiency of conversion and the transformation pathways may differ greatly due to the diversity of the resident microflora between individuals. ${ }^{5)}$ Therefore, a more uniform and targeted biological function may be achieved by providing specifically transformed ginsenosides. Few studies have been performed by edible microorganisms on the transformation of $\mathrm{Rb} 2$ and $\mathrm{Rc}$, even though they belong to the major components of the ginsenosides.

Here we have focused on understanding the transformation

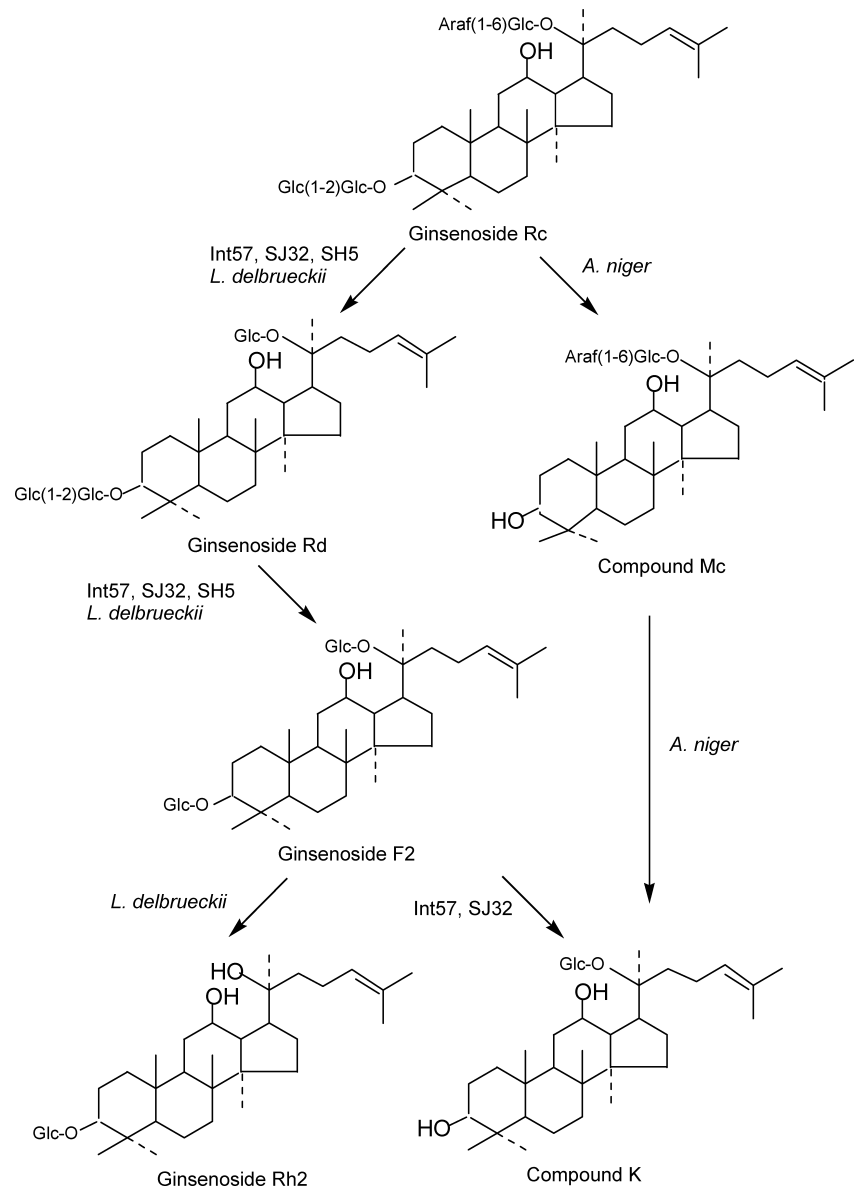

Fig. 2. Proposed Transformation Pathways of Rc by Cell-Extracts from Various Food Microorganisms

Table 3. Concentrations of Ginsenosides Transformed from Rc ${ }^{a)}$ by Cell-Free Extracts ${ }^{b)}$ from Various Food Microorganisms

\begin{tabular}{|c|c|c|c|c|c|c|c|c|c|c|c|c|}
\hline \multirow{3}{*}{ Microbes } & \multicolumn{12}{|c|}{ Transformed ginsenoside $(\mu \mathrm{M})$} \\
\hline & \multicolumn{6}{|c|}{$24 \mathrm{~h}$} & \multicolumn{6}{|c|}{$48 \mathrm{~h}$} \\
\hline & $\mathrm{Rc}$ & $\mathrm{Rd}$ & $\mathrm{F} 2$ & $\mathrm{Mc}$ & $\mathrm{CK}^{c)}$ & $\mathrm{Rh} 2$ & Rc & $\mathrm{Rd}$ & $\mathrm{F} 2$ & $\mathrm{Mc}$ & CK & $\mathrm{Rh} 2$ \\
\hline Int57 & -d) & 554 & 214 & - & 91 & - & - & - & 172 & - & 701 & - \\
\hline SJ32 & - & 765 & 94 & - & - & - & - & - & 307 & - & 554 & - \\
\hline SH5 & 89 & 745 & - & - & - & - & - & 244 & 616 & - & - & - \\
\hline L. $\mathrm{del}^{e)}$ & 705 & 24 & 31 & - & - & 62 & 18 & 22 & 54 & - & - & 768 \\
\hline A. niger & 15 & - & - & 832 & - & - & - & - & - & 735 & 88 & - \\
\hline A. usamii & 471 & 269 & 14 & 31 & 27 & - & 20 & 33 & - & 324 & 473 & - \\
\hline
\end{tabular}

a) Rc: $910 \mu \mathrm{M}$ in the original sample. b) Specific activities of $\beta$-glucosidase of the prepared microbial cell-free extracts were the same as in Table 2 . Amounts of enzymes used for the transformation reactions were: Int57, $2 \mathrm{mU}$; SJ32, $2 \mathrm{mU}$; SH5, $20 \mathrm{mU}$; L. delbrueckii, $20 \mathrm{mU} ;$ A. niger, $20 \mathrm{mU} ;$ A. usamii, $20 \mathrm{mU}$, respectively. c) CK: compound K. d) Below $10 \mu \mathrm{M}$. e) L. del: L. delbrueckii. 
of $\mathrm{Rb} 2$ and $\mathrm{Rc}$ by edible food microorganisms. The only difference between $\mathrm{Rb} 2$ and $\mathrm{Rc}$ is the configuration of the arabinose unit attached at C-20 of the ginsenoside linked by glucose. In Rb2 the arabinose is a pyranose form, and in Rc it is a furanose form. In this study, the transformation pathways of $\mathrm{Rb} 2$ and $\mathrm{Rc}$ were similar in most of the microorganisms tested. The strains Int57, SJ32, and SH5 cleaved the arabinose unit of $\alpha$-L-arabinose $(1-6)-\beta$-D-glucose- $O$ - at C-20 of $\mathrm{Rb} 2$ and $\mathrm{Rc}$ better than the glucose unit of $\beta$-D-glucose( $1-$ $2)$ - $\beta$-D-glucose- $O$ - at $\mathrm{C}$-3. In contrast, $A$. niger cleaved $\beta$-Dglucose $(1-2)-\beta$-D-glucose- $O$ - at $\mathrm{C}-3$ better than the arabinose unit of $\mathrm{Rb} 2$. It was of interest that $L$. delbrueckii produced $\mathrm{Rh} 2$ from both $\mathrm{Rb} 2$ and $\mathrm{Rc}$, unlike the other experimental microorganisms.

This is the first report of the production of $\mathrm{Rh} 2$ from $\mathrm{Rb} 2$ by bacteria. Previously, the biotransformation of Rb1 into $\mathrm{Rh} 2$ via $\mathrm{Rd}$ and $\mathrm{Rg} 3$ by the fungus Rhizopus stolonifer was reported. ${ }^{15)}$ Bae et al. reported that $\mathrm{Rb} 1$ and $\mathrm{Rb} 2$ were not metabolized to $\mathrm{Rh} 2$ by human intestinal bacteria. ${ }^{14)}$ They suggested that $\mathrm{Rb} 1$ and $\mathrm{Rb} 2$ should be transformed into $\mathrm{Rg} 3$ in the stomach to be absorbed in the form of Rh2, based on their observation that human intestinal bacteria such as $\mathrm{Bac}$ teroides sp., Fusobacterium sp., and Bifidobacterium sp. were able to transform $\mathrm{Rg} 3$ into $\mathrm{Rh} 2$. Otherwise, $\mathrm{Rb} 1$ and $\mathrm{Rb} 2$ were presumed to be metabolized to compound $\mathrm{K}$ in the human intestine. Since $L$. delbreuckii is a safe bacteria, $L$. delbreuckii-treated ginsenosides would be an effective source for providing $\mathrm{Rh} 2$ when the intake of $\mathrm{Rh} 2$ is desired.

The functions of Rh2 and compound K, which are the specific final products for the respective enzymes in this study, have been reported. The major activities for $\mathrm{Rh} 2$ include inhibition of the initiation and progression of tumor cells. ${ }^{16)}$ $\mathrm{Rh} 2$ inhibits the growth of B16 melanoma cells. The production of nitric oxide by IFN gamma plus LPS-treated macrophages is markedly reduced by $\mathrm{Rh} 2$, but is not inhibited by $\mathrm{Rb} 1, \mathrm{Rc}$, or Re. ${ }^{17)}$ Compound $\mathrm{K}$ is known to induce an antimetastatic or anticarcinogenic effect by blocking tumor invasion or preventing chromosomal activation and tumorigenesis. ${ }^{18)}$ From the above reports, the transformed products of $\mathrm{Rb} 2$ and $\mathrm{Rc}$ by the food microbial enzymes used in this experiment would be used as an anticarcinogenic food compound. Our experimental demonstration that various edible microorganisms produce specific forms of ginsenosides may indicate that it is feasible to develop a specific bioconversion process to obtain specifically designed functional products by the appropriate combination of ginsenoside substrates and specific microbial enzymes.

Acknowledgment This work was supported by the Ministry of Science and Technology (grant no. M1-0302-000098).

\section{REFERENCES}

1) Sato K., Mochizuki M., Saiki I., Yoo Y. C., Samukawa K., Azuma I., Biol. Pharm. Bull., 17, 635-639 (1994).

2) Mochizuki M., Yoo C. Y., Matsuzawa K., Sato K., Saiki I., Tono-oka S., Samukawa K., Azuma I., Biol. Pharm. Bull., 18, 1197-1202 (1995).

3) Tawab M. A., Bahr U., Karas M., Wurglics M., Schubert-Zsilavecz M., Drug Metab. Dispos., 31, 1065-1071 (2003).

4) Bae E. A., Park S. Y., Kim D. H., Biol. Pharm. Bull., 23, 1481-1485 (2000).

5) Lee D. S., Kim Y. S., Ko C. N., Cho K. H., Bae H. S., Lee K. S., Kim J. J., Park E. K., Kim D. H., Arch. Pharm. Res., 25, 165-169 (2002).

6) Han B. H., Park M. H., Han Y. N., Woo L. K., Sankawa U., Yahara S., Tanaka O., Planta Med., 44, 146-149 (1982).

7) Chen Y., Nose M., Ogihara Y., Chem. Pharm. Bull., 35, 1653-1655 (1987).

8) Hasegawa H., Sung J. W., Benno Y., Planta Med., 63, 463-440 (1997).

9) Bae E. A., Kim N. A., Han M. J., Choo M. K., Kim D. H., J. Microbiol. Biotechnol., 13, 9-14 (2003).

10) Bae E. A., Han M. J., Kim E. J., Kim D. H., Arch. Pharm. Res., 27, 61-67 (2004).

11) Ko S. R., Suzuki Y., Choi K. J., Kim Y. H., Biosci. Biotechnol. Biochem., 64, 2739-2743 (2000).

12) Ko S. R., Choi K. J., Uchida K., Suzuki Y., Planta Med., 69, 285-286 (2003).

13) Park S. Y., Ji G. E., Ko Y. T., Jung H. K., Ustunol Z., Pestka J. J., Int. J. Food Microbiol., 46, 231-241 (1999).

14) Bae E. A., Han M. J., Choo M. K., Park S. Y., Kim D. H., Biol. Pharm. Bull., 25, 58-63 (2002).

15) Aling D., Min Y., Hongzhu G., Junhua Z., Dean G., Biotechnol. Lett., 25, 339-344 (2003).

16) Kim H. S., Lee E. H., Ko S. R., Choi K. J., Park J. H., Im D. S., Arch. Pharm. Res., 27, 429-435 (2004).

17) Park Y. C., Lee C. H., Kang H. S., Kim K. W., Chung H. T., Kim H. D., Biochem. Mol. Biol. Int., 40, $751-757$ (1996).

18) Lee S. J., Ko W. G., Kim J. H., Sung J. H., Moon C. K., Lee B. H., Biochem. Pharmacol., 60, 677-685 (2000). 